\title{
Influence of the Use of Liquefied Petroleum Gas (LPG) Systems in Woodchippers Powered by Small Engines on Exhaust Emissions and Operating Costs
}

\author{
Łukasz Warguła $^{1, * \mathbb{C}}$, Mateusz Kukla ${ }^{1}{ }^{(\mathbb{D}}$, Piotr Lijewski $^{2}$, Michał Dobrzyński ${ }^{2}$ and \\ Filip Markiewicz ${ }^{2}$ \\ 1 Institute of Machine Design, Faculty of Mechanical Engineering, Poznan University of Technology, \\ Piotrowo 3, PL-60965 Poznan, Poland; mateusz.kukla@put.poznan.pl \\ 2 Institute of Internal Combustion Engines and Drives, Faculty of Civil Engineering and Transport, \\ Poznan University of Technology, Piotrowo 3, PL-60965 Poznan, Poland; piotr.lijewski@put.poznan.pl (P.L.); \\ michal.dobrzynski@put.poznan.pl (M.D.); filip.markiewicz@put.poznan.pl (F.M.) \\ * Correspondence: lukasz.wargula@put.poznan.pl; Tel.: +48-(61)-665-20-42
}

Received: 12 August 2020; Accepted: 3 November 2020; Published: 4 November 2020

check for updates

\begin{abstract}
The use of alternative fuels is a contemporary trend in science aimed at the protection of non-renewable resources, reducing the negative impact on people and reducing the negative impact on the natural environment. Liquefied petroleum gas (LPG) is an alternative fuel within the meaning of the European Union Directive (2014/94/UE), as it is an alternative for energy sources derived from crude oil. The use of LPG fuel in low-power internal combustion engines is one of the currently developed scientific research directions. It results from the possibility of limiting air pollutant emissions compared to the commonly used gasoline and the lower cost of this fuel in many countries. By "gasoline 95" the Authors mean non-lead petrol as a flammable liquid that is used primarily as a fuel in most spark-ignited internal combustion engines, whereas 95 is an octane rating (octane number). This article presents the results of research on fuel consumption, toxic exhaust gas emission, and operating costs of a woodchipper used for shredding branches with a diameter of up to $100 \mathrm{~mm}$ in real working conditions. The woodchipper, powered by a $9.5 \mathrm{~kW}$ internal combustion engine, fueled by gasoline and LPG was tested. Liberal regulations of the European Union (Regulation 2016/1628/EU) on the emission of harmful exhaust compounds from small spark-ignition engines (up to $19 \mathrm{~kW}$ ) and non-road applications contribute to the low technical advancement level of these engines. The authors researched a relatively simple and cheap LPG fueling system, as in their opinion, such a system has the best chance of being implemented for use. In the study, the branches of cherry plum were shredded (Prunus cerasiferaEhrh. Beitr. Naturk. 4:17. 1789 (Gartenkalender4:189-204. 1784)). Their diameter was ca. $80 \mathrm{~mm}$, length $3 \mathrm{~m}$, and moisture content ca. $25 \%$. The system was tested during the shredding of the branches in real working conditions (the frequency of supplying the branches about $4 \mathrm{~min}^{-1}$ and the mass productivity of about $0.73 \mathrm{t} / \mathrm{h}$ ). Based on the recorded results, it was found that the LPG fueled engine was characterized by higher carbon monoxide (CO) and nitrogen oxides $\left(\mathrm{NO}_{\mathrm{x}}\right)$ emissions by $22 \%$ and $27 \%$, respectively. A positive effect of using LPG was the reduction of fuel consumption by $28 \%$ and carbon dioxide $\left(\mathrm{CO}_{2}\right)$ and hydrocarbons $(\mathrm{HC})$ emissions by $37 \%$ and $83 \%$, respectively. The results of the research show that the use of alternative fuels can bring benefits in terms of $\mathrm{CO}_{2}$ and $\mathrm{HC}$ emissions, but at the same time be characterized by an increase in $\mathrm{CO}$ and $\mathrm{NO}_{\mathrm{x}}$ emissions. Further research should be conducted on innovative alternative fuel supply systems, such as in the automotive industry. At the same time, legislators should limit the use of low-quality fuel supply systems with the limits of pollutant emissions in exhaust gases, contributing to the development and economic competitiveness of new fuel injection systems.
\end{abstract}

Keywords: small engine; woodchipper; liquefied petroleum gas LPG; alternative fuels; toxic exhaust gases emission 


\section{Introduction}

Air pollution in urban areas is a serious environmental problem in many cities around the world (e.g., Europe [1], Asia [2], North America [3], South America [4], Australia [5], and Africa [6]). Green infrastructure has been lost in many urban areas as a result of population growth and urbanization. One way to improve air quality is to increase green areas (for example parks) in cities [7]. The most important problem of modern cities is the loss of urban green areas [7]. Reducing their surface increases air pollution [8], and above all its dustiness [9]. Considering that scientists are working on determining the species of plants that will be used in urban areas, the increase in the demand for machinery and equipment necessary for the care of these plants is noticeable. Different equipment and machines are used for wood chipping and shredding after the pruning or felling in urban areas (home gardens, parks, or roadsides) than in forests or industrial biomass production areas. As indicated in the literature [10] on the subject the industrial woodchippers are characterized by a drive unit ranging in mechanical power from $130 \mathrm{~kW}$ up to $900 \mathrm{~kW}$. Chippers used for works in urbanized areas are mainly driven by spark-ignition internal combustion engines, whose power usually does not exceed $19 \mathrm{~kW}$ [11]. These machines are characterized by relatively small parameters of wood chips production efficiency [12] and are not intended for biomass processing on an industrial scale. Woodchippers are classified as non-road machines. For this reason, they are subject to quite liberal legal regulations as compared to the provisions on internal combustion engines used in motor vehicles [13]. They are associated with the emission of toxic exhaust gases, and thus directly affect the technical advancement of the engine fuel supply system. As a result of the lack of appropriate regulations, internal combustion engines used in chippers are characterized by high toxicity of the emitted exhaust fumes and contribute significantly to air pollution. This problem is noticed by the authors and other researchers, which is why development is currently underway towards fuel injection systems, [14-16] systems adapting the drive to the conditions of use [17-19], improving durability [20], and alternative fuels (e.g., liquefied petroleum gas (LPG) [21-25], ethanol [26,27]) for small spark-ignition engines; however, no regulations limit the use of outdated technologies. The relatively high cost of drives with the injection system is the result of their low popularity in the industry [28].

Fuel supply systems in spark-ignition engines have been developing dynamically since the use of electronic control. In motor vehicles, carburetor fuel supply systems using hydrodynamic Bernoulli equations for fuel dosing were superseded in the 1990s. The development of injection systems led to electronic fuel injection integration with the ignition timing system. The expansion of these systems with an oxygen content sensor in the exhaust gas made it possible to regulate the fuel mixtures in terms of stoichiometric mixtures. In turn, the injection systems in the processes of regulating the composition of the air-fuel mixture took into account the need to select the optimal mixture for the correct operation of exhaust gas treatment systems, e.g., three-way catalytic reactors. Currently, the best injection systems feature a multiphase direct injection into the combustion chamber. The same trend is developed for LPG; however, for this fuel, differences in systems can be distinguished due to its phase. The first LPG systems provided the fuel in the combustion chamber in the gaseous phase by indirect injection into the intake manifold; however, the latest systems with direct injection into the combustion chamber are characterized by the use of LPG in the liquid phase. Vehicles powered by such fuel supply systems meet the highest emission standards [13]. On the other hand, in non-road machines with small engines, the carburetor systems are acceptable and commonly used. Their technical advancement is at a lower level than the available solutions used in, for example, transport, and despite this, they comply with the European regulations on exhaust emissions

In order to successfully become a large part of the fuel market, alternative fuels must be widely available for sale. One of the alternative fuels to gasoline 95, commonly used all over the world, is LPG. It is characterized by relatively easy availability (and a competitive price). The breakdown of 
LPG and gasoline prices in Europe and Asia are presented in Figures 1 and 2, respectively. The same comparison for America and Oceania is shown in Figure 3. There is a trend associated with attempts to use LPG as an alternative fuel to gasoline. This has economic benefits, as LPG is cheaper than gasoline in the vast majority of countries around the world. There are also possible ecological effects related to the comparison of the toxicity of gases resulting from the combustion of LPG and gasoline; however, it depends on the degree of technical advancement as well as the settings and parameters of the drive system of machines and vehicles [29]. It is possible to indicate the conditions for which the results of the toxicity of gases generated as a result of LPG combustion will be worse than during gasoline combustion [29] and vice versa [30]. Despite this fact, research works aimed at adapting gasoline engines to the combustion of gaseous fuels (e.g., LPG or compressed natural gas (CNG)) is an important direction of development, because in the future they can be replaced with more environmentally beneficial biogas, e.g., from wastewater treatment [31].
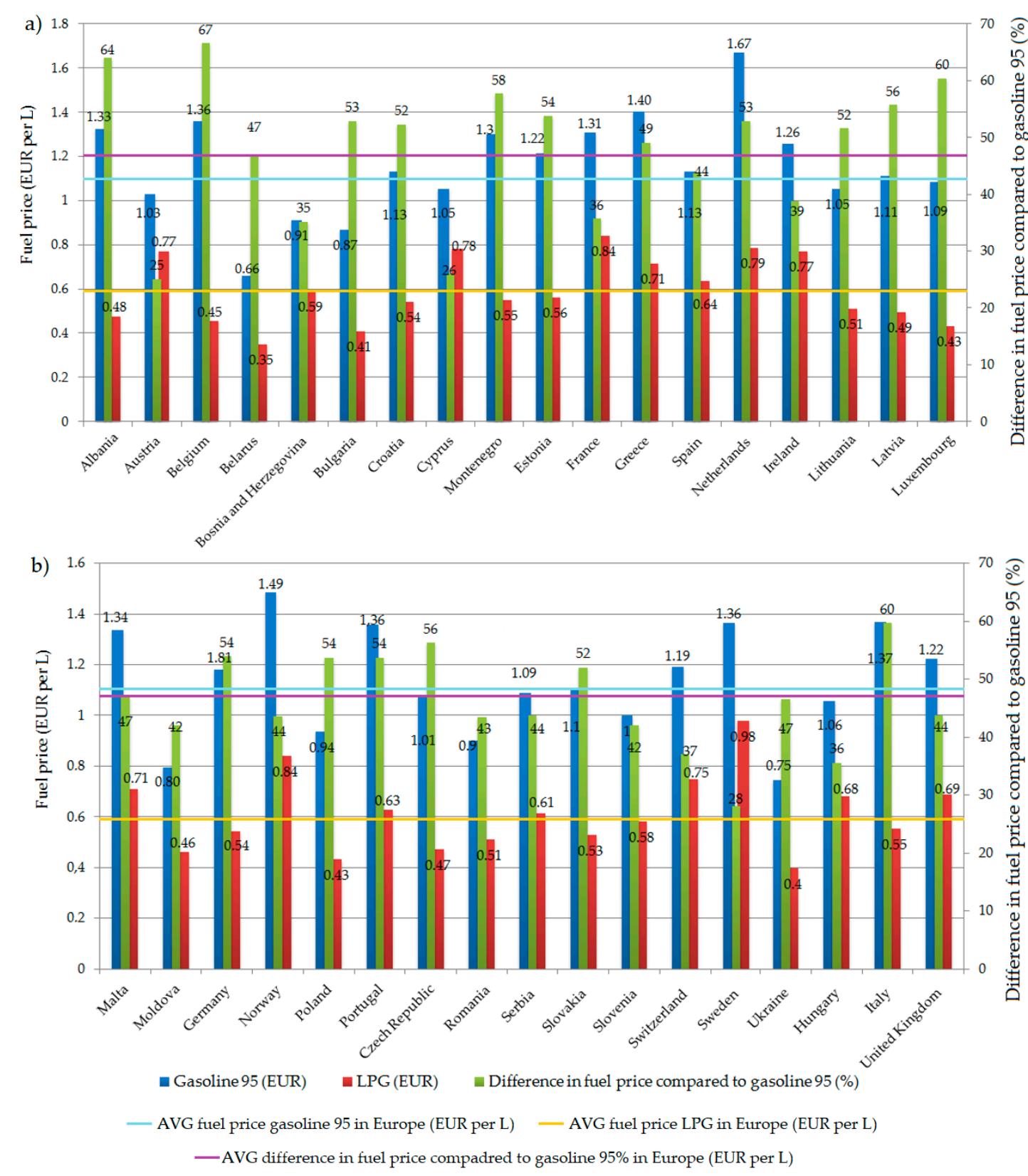

Figure 1. Price of gasoline 95 and liquefied petroleum gas (LPG) in selected European countries from 20 July 2020, where (a) part 1, (b) part $2[32,33]$. 


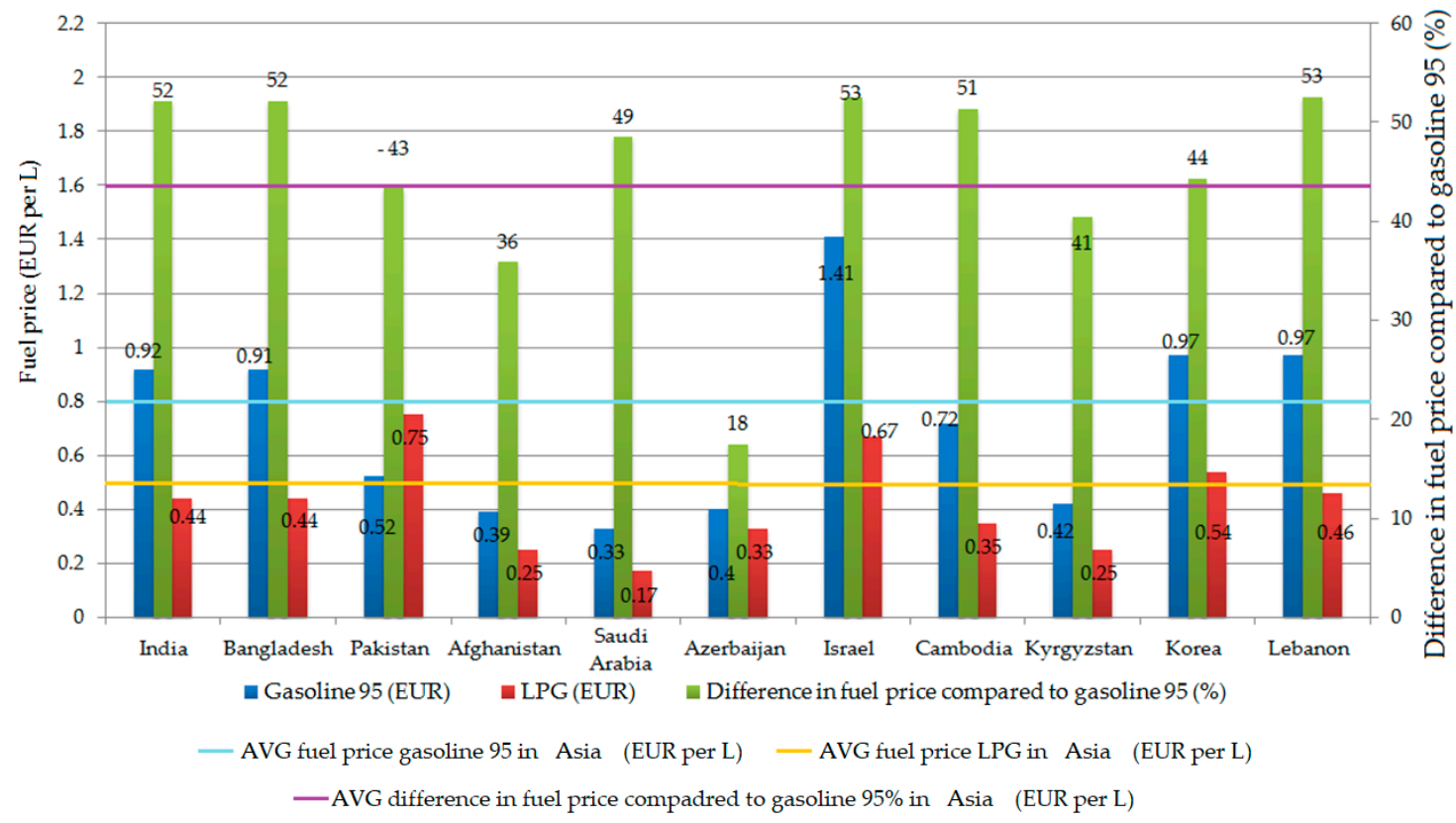

Figure 2. Price of gasoline 95 and LPG in selected Asian countries from 20 July 2020 [32,33].

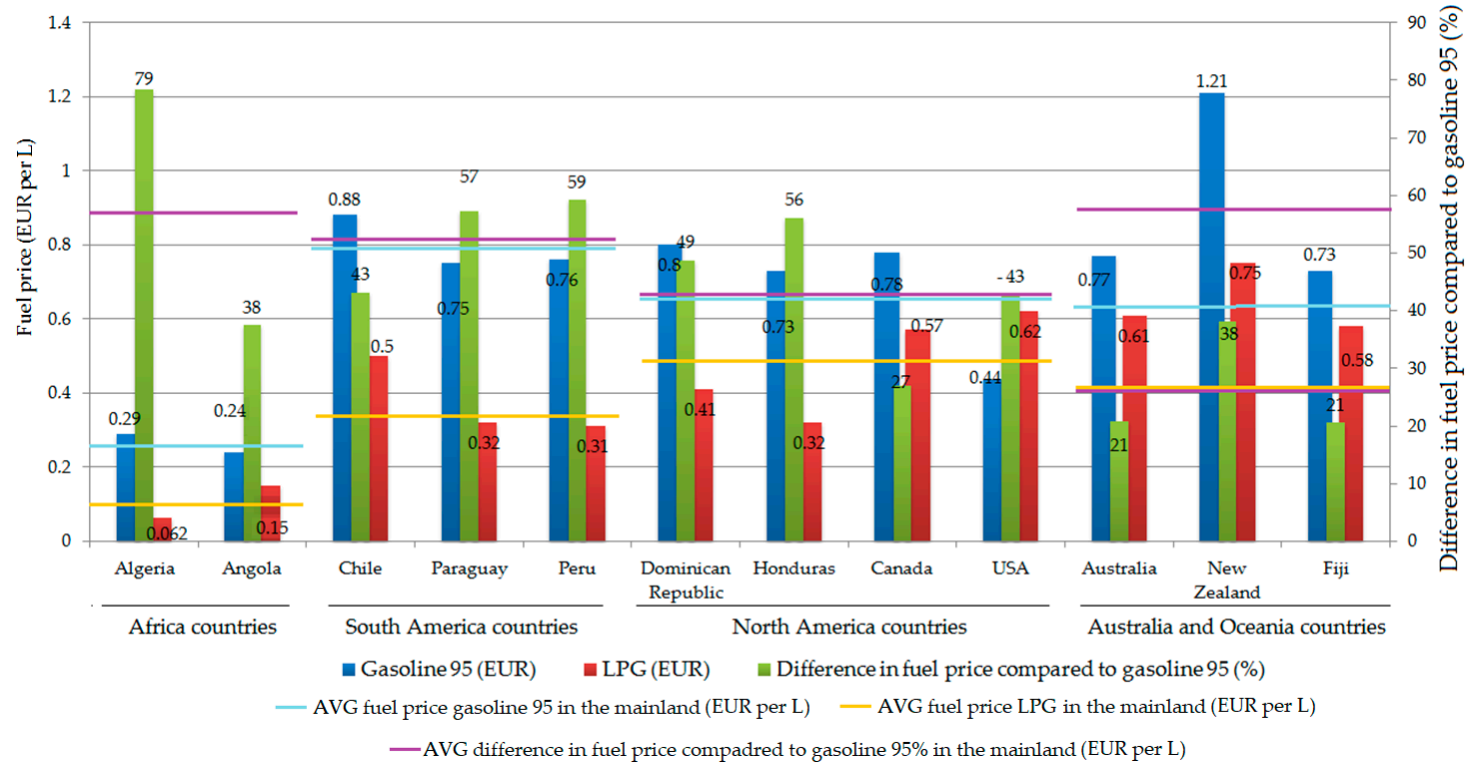

Figure 3. Price of gasoline 95 and LPG in selected African, South American, North American, and Oceanic countries from 20 July $2020[32,33]$.

Research on the use of LPG fuel in internal combustion engines shows different conclusions as to the effects of their application. The authors of [34] presented the results of tests of a compression-ignition internal combustion engine (cylinder capacity $296 \mathrm{~cm}^{3}$ and $5.59 \mathrm{~kW}$ ) powered by two types of fuel (diesel and LPG in different ratios), showing that the use of LPG injected in the liquid phase to the fuel may reduce $\mathrm{CO}$ and $\mathrm{HC}$ emissions by about $20-30 \%$ and increase $\mathrm{NO}_{\mathrm{x}}$ emissions by $6 \%$ [34]. A comparative study of the energy and ecological parameters of dual-fuel engines (diesel- natural gas (NG) and hydrotreated vegetable oil (HVO)-biogas) and conventional diesel oil in a compression-ignition engine showed that the use of methane in the dual-fuel mixture reduced the $\mathrm{CO}_{2}$ volume in the exhaust by $17-20 \%$, and biomethane increased the $\mathrm{CO}_{2}$ volume by $10-14 \%$. Using two fuels significantly increased the emissions of $\mathrm{CO}$ (by about 24 times) and $\mathrm{HC}$ (by about 28 times), but the $\mathrm{NO}_{\mathrm{x}}$ volume decreased by $67-82 \%$, and the smoke emitted by the engine decreased by $23-39 \%$ [35]. Efficient and 
ecological indicators of a compression-ignition engine powered by various mixtures of diesel oil and LPG indicate that additional LPG reduces the volume of diesel fuel injected into the cylinder and causes a delay in the start of injection, thus affecting the combustion process of the fuel mixture and reducing the efficiency of the engine. Increasing the share of LPG causes an increase in the concentrations of incomplete fuel combustion products, such as $\mathrm{CO}$ and $\mathrm{HC}$ as well as smoke; however, $\mathrm{NO}_{\mathrm{x}}$ and $\mathrm{CO}_{2}$ emissions are decreasing [36]. The observed trend suggests that alternative fuels for internal combustion engines can reduce the negative environmental impact of those engines [37]; however, research results are showing that LPG-powered internal combustion engines are characterized by a higher emission of harmful exhaust gas compounds compared to gasoline-powered engines [29]. These studies have shown that the level of emission of harmful exhaust gas compounds is dependent on the type, or rather a generation, of the gas installation used. Older generation installations may have less favorable effects of using alternative fuel [29]. The competitive design of fuel supply systems in terms of installation costs for small engines is the first-generation installations, which are now ready for implementation, In order to evaluate the available structures in terms of the emission of harmful exhaust compounds and fuel consumption, tests were performed in the actual operating conditions of the machines. Such measurements are possible thanks to portable emission measurement systems (PEMS) which, according to scientists, should be used for road approval and homologation in the future [38].

The article presents research that is a part of the global trend of research on machines and vehicles in real operating conditions. The study was carried out on a small engine driving woodchipper created for use in urban areas. The engine was powered by gasoline 95 and after the modernization of the fuel supply system, by LPG. A commercial power supply system was used, and the modernization cost was EUR 105. The research aimed to show the differences in the emission of harmful exhaust gas compounds and the operating costs of the machine by comparing the combustion engine when fueled by either gasoline 95 or LPG.

\section{Materials and Methods}

The subject of performed research was a Red Dragon RS-100 (Remet CNC Technology Sp. Z O.O., Kamien, Poland) woodchipper presented in Figure 4a. This is a commonly used machine for chipping branches in urbanized areas. The specification of the chipper is shown in Table 1. The chipper with the factory settings (A) was driven by the spark-ignition engine Lifan GX390 (License: American Honda Motor Company, Inc., Torrance, CA, United States), $9.5 \mathrm{~kW}$ (Figure 4b). The specification of the drive is shown in Table 1. The tested drive unit characteristics in terms of power, torque, and fuel consumption are shown in Figure 5a. The efficiency characteristics of engines determined based on the input and output energy are shown in Figure 5b. Then, the original design (A) was modernized to the second version (B). In version (B) the carburetor powered by gasoline 95 was replaced by a carburetor system adapted to use a mixture of propane and butane as fuel. The modified carburetor powered by LPG is presented in Figure 4c. It is an innovative system in this group of engines, and it is commercially available as an upgrade system. The modernization of the gasoline 95 engine and its most essential components and cost are presented in Table 2. A modernized engine with an LPG fuel system was installed in a woodchipper with a branch logger mechanism. The designs (A) and (B) were adjusted before the tests following the rules of regulating the tested carburetors for stoichiometric mixtures (AFR). For design (A) that used gasoline 95 this value was equal to 14.7: 1; for design (B) that used LPG fuel this value was equal to 15.5: 1 . Tests were performed to compare the emission of harmful exhaust gas compounds: $\mathrm{CO}_{2}, \mathrm{CO}, \mathrm{HC}$, and $\mathrm{NO}_{\mathrm{x}}$ emitted by the chipper powered by gasoline 95 and LPG engine. The tests were carried out in real operating conditions. During the tests, the chipper shredded branches with a diameter of up to $100 \mathrm{~mm}$, for which its cutting mechanism was designed. The characteristic of the fuels used during the tests is presented in Table 3. 

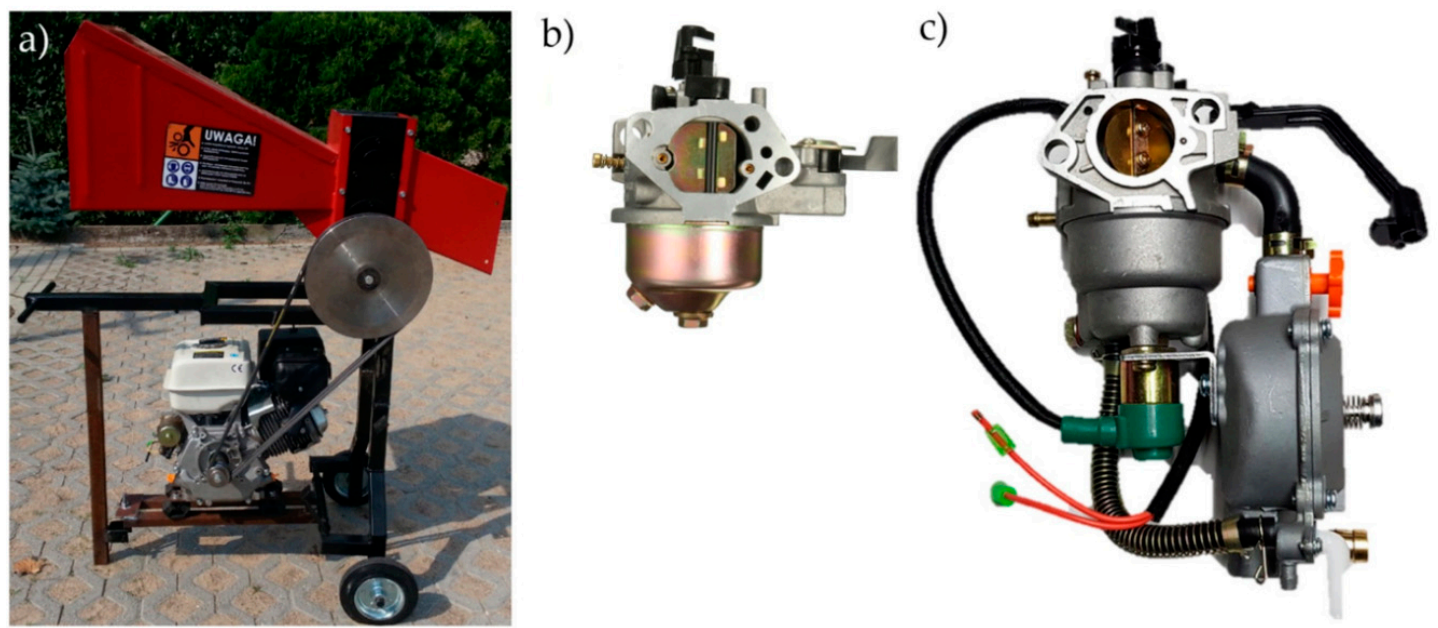

Figure 4. The tests were carried out on (a) woodchipper with branch logger mechanism, (b) carburetor system adapted to gasoline 95, (c) carburetor system adapted to LPG.

Table 1. Technical specification of woodchipper Red Dragon RS-100 and Lifan GX390 engine.

\begin{tabular}{cc}
\hline \multicolumn{1}{c}{ Woodchipper Red Dragon RS-100 } \\
\hline Parameter & Characteristic \\
\hline $\begin{array}{c}\text { Cutting mechanism type } \\
\text { Cut branches maximal diameter } \\
\text { Lverage mass flow rate [12] }\end{array}$ & Cylindrical \\
Lut branches length (mechanism has 4 knives) & $100 \mathrm{~mm}$ \\
Average volumetric flow rate [12] & $0.66 \mathrm{t} / \mathrm{h}$ \\
& $3.5 \mathrm{~m}^{3} / \mathrm{h}$ \\
\hline Parameter & \\
\hline Swept volume & Characteristic \\
\hline Engine maximal power at 3600 rpm & $389 \mathrm{~cm}{ }^{3}$ \\
Engine maximal torque at 2500 rpm & $9.56 \mathrm{~kW} / 13 \mathrm{HP}$ \\
Bore/Stroke & $26.5 \mathrm{Nm}$ \\
Engine Type & $88 \mathrm{~mm} / 64 \mathrm{~mm}$ \\
Number of cylinders & Four-stroke, OHV (Over Head Valve) \\
Ignition & 1 \\
Weight & Electronic, without ignition timing adjustment [39] \\
Average cost & $31 \mathrm{~kg}$ \\
& 270 EUR \\
\hline
\end{tabular}

Table 2. Cost of components and services for modernizing a small engine to be powered by LPG.

\begin{tabular}{cc}
\hline System Components and Service & Cost \\
\hline CPG gas reducer with pressure gauge & $46 €$ \\
Installation hose & $7 €$ \\
$11 \mathrm{~kg}$ gas tank & $6 €$ \\
Working time spent on the modernization of the structure and system regulation $1 \mathrm{~h}$ & $23 €$ \\
\hline
\end{tabular}


a)

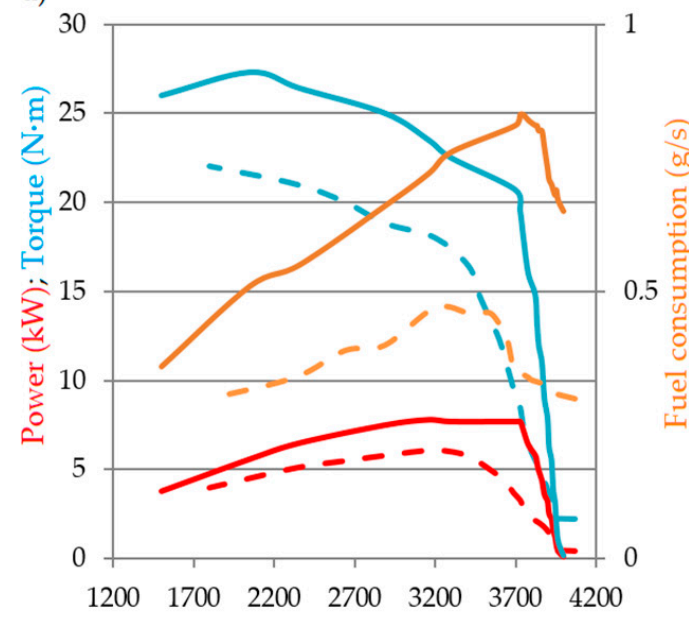

Combustion engine powered by gasoline 95 b)

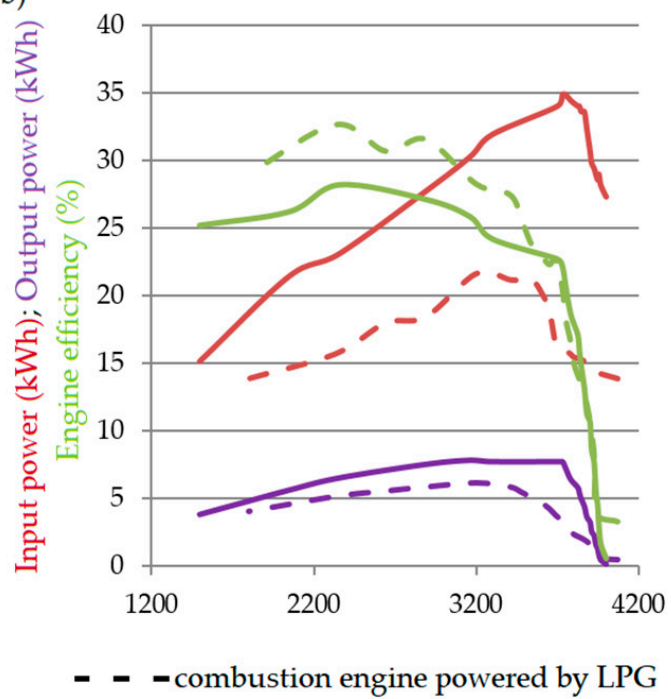

Figure 5. Characteristics of the German iGX engine powered by gasoline and LPG, in terms of (a) power, torque, fuel consumption, and efficiency; (b) efficiency, energy input, and energy output. The colors correspond to the individual physical quantities, and the line type to the type of fuel.

Table 3. Properties of tested fuels, where $\mathrm{MON}=$ motor octane number; $\mathrm{RON}=$ research octane number [40].

\begin{tabular}{ccc}
\hline Fuel & Gasoline 95 & $\begin{array}{c}\text { Liquefied Petroleum Gas } \\
\text { Propane-Butane 50\%/50\% }\end{array}$ \\
\hline Density under reference conditions & 520 \\
(liquid phase) $\left(\mathrm{kg} / \mathrm{m}^{3}\right)$ & $720-775$ & 46 \\
Fuel calorific value $(\mathrm{MJ} / \mathrm{kg})$ & 42.6 & -30 \\
Boiling temperature $\left({ }^{\circ} \mathrm{C}\right)$ & $40-210$ & $0.4-1.7$ \\
Excess air coefficient $\lambda$ up to the ignitability boundaries & $0.4-1.4$ & $95(100)$ \\
Octane number MON (RON) & $85(95)$ & $15.5: 1$ \\
Air fuel ratio (AFR) for stoichiometric mix (mass) & $14.7: 1$ & \\
\hline
\end{tabular}

The branches of cherry plum (Prunus cerasiferaEhrh. Beitr. Naturk. 4:17. 1789 (Gartenkalender4: 189-204. 1784)) were shredded. Their diameter was ca. $80 \mathrm{~mm}$, length $3 \mathrm{~m}$, and moisture content ca. about $25 \%$. The moisture content of selected branches was checked before and during the tests; the branches came from different places in the branch pile. The moisture test was carried out using a METTLER TOLEDO HR83 moisture analyzer (Mettler Toledo, Columbus, OH, United States). Branches with such parameters take about $4.5 \mathrm{~s}$ to be chipped in a cylindrical chipper [17]. Branches of similar diameters and lengths generated a similar machine load, which translated into a more uniform chipping time. Such branches should be considered typical. They put a heavy load on the machine. The tested specimens were representative of hardwood species in accordance with the Janka classification [41]. The Janka hardness test measures the resistance of a sample of wood to denting and wear. It measures the force required to drive a steel drive of an $11.28 \mathrm{~mm}(0.444 \mathrm{in})$ diameter halfway into a sample of wood [42,43]. The branches were stashed at a distance of $2 \mathrm{~m}$ from the chipper and were fed by one experienced operator. During the test, based on signals from the optical system in the feed channel, the branch feeding frequency was recorded. The recorded results are presented in Table 4 . The branch feeding frequency in all samples was close to $4 \mathrm{~min}^{-1}$. The second parameter characterizing the chipping machines' working conditions is the average mass flow rate of the shredded material. This value was determined based on shredded branches' mass measurements as a time function using a portable scale (Radlastplattform up to $1500 \mathrm{~kg}$, meeting the requirements of ISO 9001). The mass flow rate measurement results depending on the different configurations of the machine are presented in Table 4 . The average mass productivity of the chipper during the tests was $0.73 \mathrm{t} / \mathrm{h}$. The results of 
measurements of the frequency of branch delivery and mass productivity during the research were determined as being at a similar level, which allows concluding that the machines in both tests were subject to comparable operating conditions.

Table 4. Branch feeding frequency in measurement samples and cylindrical chipper mass flow rate during tests, where a: Gasoline supply system; B: LPG supply system.

\begin{tabular}{ccc}
\hline Tested Design & A & B \\
\hline Average branch feeding frequency & $3.9 \mathrm{~min}^{-1}$ & $4.1 \mathrm{~min}^{-1}$ \\
Cylindrical chipper mass flow rate & $0.75 \mathrm{t} / \mathrm{h}$ & $0.71 \mathrm{t} / \mathrm{h}$ \\
\hline
\end{tabular}

Exhaust emissions were tested using Axion RS+, a typical portable emissions measurement system (PEMS) from Global MRV. Table 5 presents its technical specification. In the research emission levels of $\mathrm{CO}_{2}$, hydrocarbon $(\mathrm{HC})$, carbon monoxide $(\mathrm{CO})$, carbon dioxide $\left(\mathrm{CO}_{2}\right)$, and nitrogen oxides $\left(\mathrm{NO}_{\mathrm{x}}\right)$ were analyzed. Based on the carbon balance, we determined fuel consumption according to Equation (1) [44]:

$$
F C=1.153\left[(0.866 \cdot \mathrm{HC})+(0.429 \cdot \mathrm{CO})+\left(0.273 \cdot \mathrm{CO}_{2}\right)\right],
$$

where $F C$ is the fuel consumption $(\mathrm{g} / \mathrm{s}) ; \mathrm{HC}, \mathrm{CO}$, and $\mathrm{CO}_{2}$ are the emission of harmful ingredients $(\mathrm{g} / \mathrm{s})$.

Table 5. Characteristics of Axion RS, a portable exhaust emissions analyzer [44].

\begin{tabular}{cccc}
\hline Gas & Measurement Range & Sensitivity & Characteristic \\
\hline HC Propane & $0-4000 \mathrm{ppm}$ & $\pm 3 \%$ & $1 \mathrm{ppm}$ \\
$\mathrm{CO}$ & $0-10 \%$ & $\pm 3 \%$ & $0.01 \mathrm{vol} \%$ \\
$\mathrm{CO} 2$ & $0-16 \%$ & $\pm 3 \%$ & $0.01 \mathrm{vol} \%$ \\
$\mathrm{NOx}$ & $0-4000 \mathrm{ppm}$ & $\pm 4 \%$ & $1 \mathrm{ppm}$ \\
$\mathrm{O} 2$ & $0-25 \%$ & $\pm 3 \%$ & $0.01 \mathrm{vol} \%$ \\
\hline
\end{tabular}

The device used measured the concentrations expressed in vol.\% or ppmv. As a result, more measurable emissions are determined.

\section{Results}

The results of the hourly emissions of harmful exhaust gas compounds and fuel consumption for the chipper powered by a gasoline 95 and LPG engine are shown in the figures: CO (Figure 6), $\mathrm{CO}_{2}$ (Figure 7), $\mathrm{HC}$ (Figure 8), $\mathrm{NO}_{\mathrm{x}}$ (Figure 9) together with the fuel consumption during the shredding process (Figure 10) as a function of time. The presented descriptions show greater changes in the instantaneous emission value for an LPG-powered engine, and this applies to all harmful compounds. These instantaneous changes (peaks), both for the gasoline 95 and LPG engine, result from changes in the engine load, which is the result of supplying branches to the chipper. It follows that the emission from the LPG-powered engine shows a greater susceptibility to load changes. Average values of hourly emissions of harmful exhaust gas compounds: $\mathrm{CO}$ and $\mathrm{NO}_{\mathrm{x}}$ (Figure 11) are higher, whereas $\mathrm{CO}_{2}$ and $\mathrm{HC}$ emissions are lower for the LPG-powered engine. The description of $\mathrm{CO}$ emissions as a function of time shows that the LPG-powered engine is characterized by higher emissions, which is related to the control of the fuel-air mixture composition in the scope of lean mixtures. Constructions powered by LPG was characterized by lower fuel consumption. For nitrogen oxides $\left(\mathrm{NO}_{\mathrm{x}}\right)$ to be created, the combustion temperature must be high, and there must be free oxygen molecules. Hence, $\mathrm{NO}_{\mathrm{x}}$ emissions are most often associated with the combustion of a lean mixture, i.e., with an excess of air over fuel compared to a stoichiometric mixture. This parameter is also unfavorable for the LPG-powered design. One positive aspect of the LPG-powered design is the reduction in HC emissions. The HC emissions are due to the unburnt fuel particles in the exhaust gas. The lower HC emission indicates that the LPG-powered engine under the periodically variable loading conditions was characterized by a less rich mixture than 
the gasoline-powered design (Figure 12) [10,45]. The air-fuel ratio (AFR) characteristics during the chopping processes are also presented. A direct comparison of the characteristics of the engine fueled by gasoline and LPG fuel is not justified as the AFR value for the stoichiometric mixtures of these fuels is different (14.7 for gasoline and 15.5 for LPG); however, the individual nature of the work of the tested engines can be observed. The gasoline-powered engine has a rich mixture under the tested operating conditions (avg $\approx 13.2 \pm 0.03$ ) and maintains it relatively stable. The average AFR value differs from the stoichiometric mixture by about $10 \%$. On the other hand, the LPG-powered engine has a rich mixture (avg $\approx 15.1 \pm 0.3$ ), but its operation is less stable and is characterized by much greater fluctuations of the AFR value. In this case, the average AFR value deviates from the stoichiometric mixture by about $2.5 \%$. This indirectly contributes to the higher efficiency of this engine, as shown in Figure $5 \mathrm{~b}$. As the supplied fuel is largely completely burned and converted into energy.

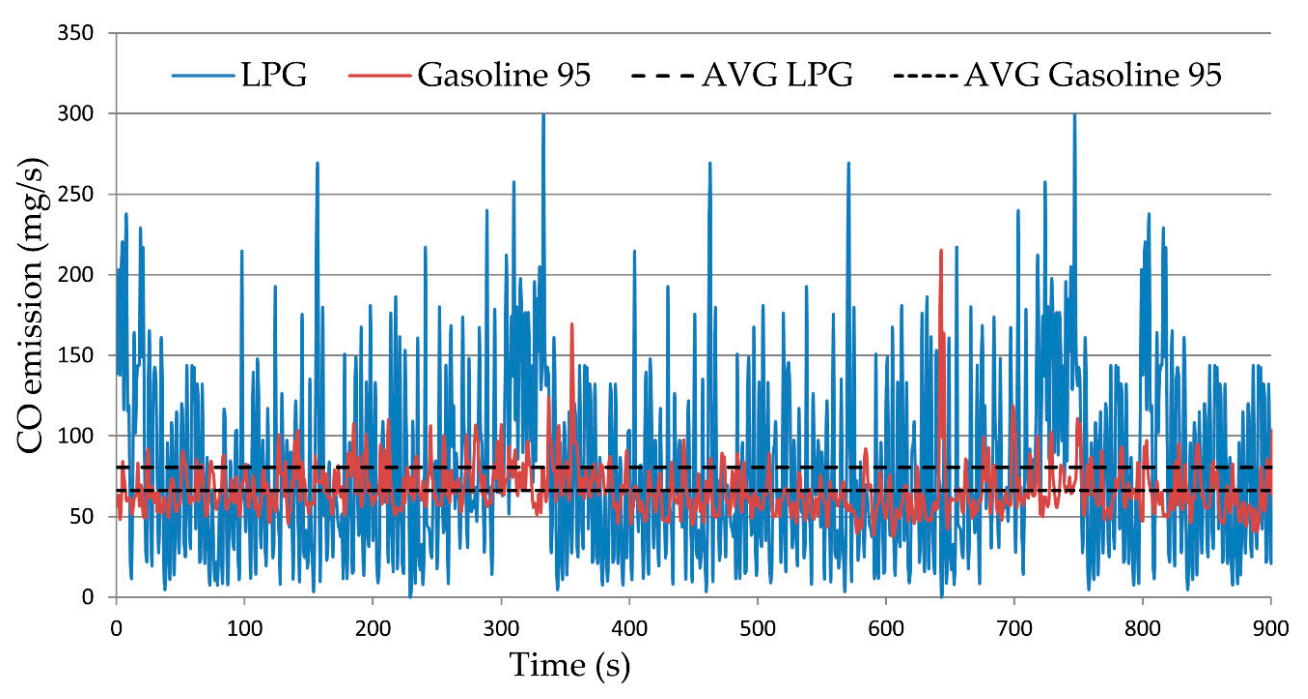

Figure 6. $\mathrm{CO}$ emission as a time function during the chipping process.

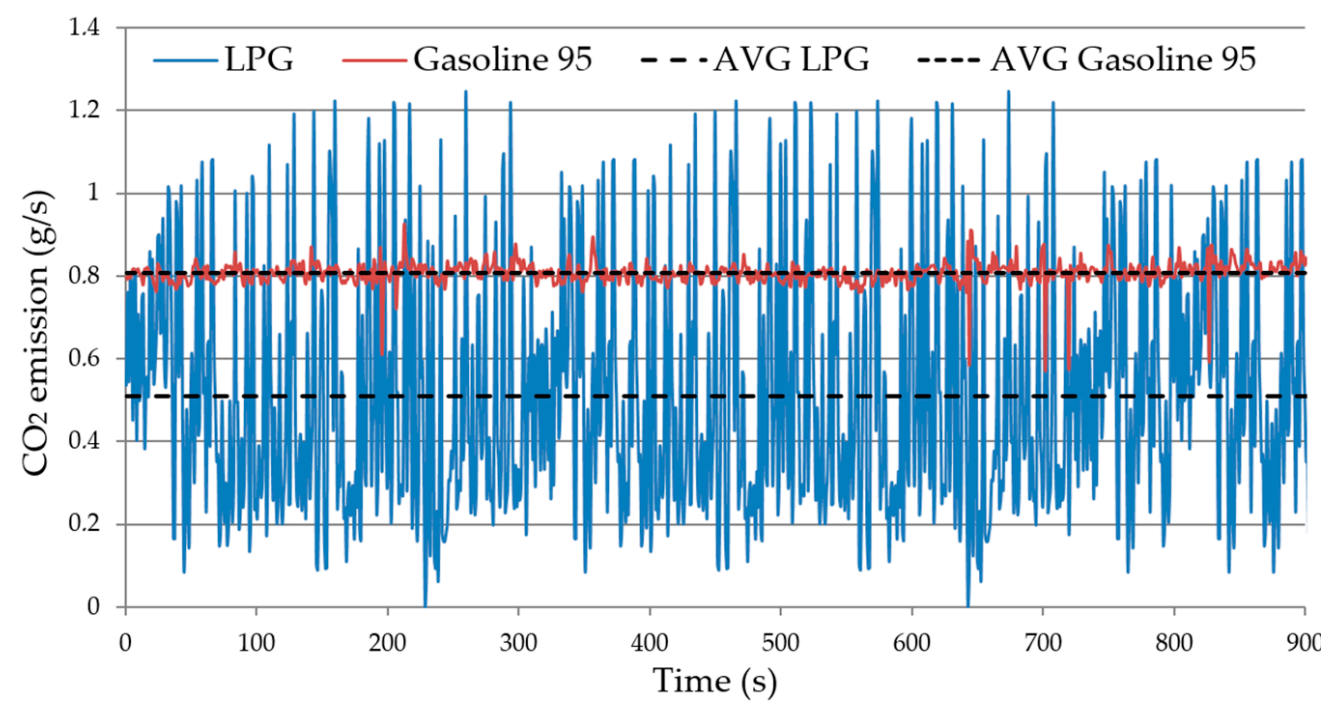

Figure 7. $\mathrm{CO}_{2}$ emission as a time function during the chipping process. 


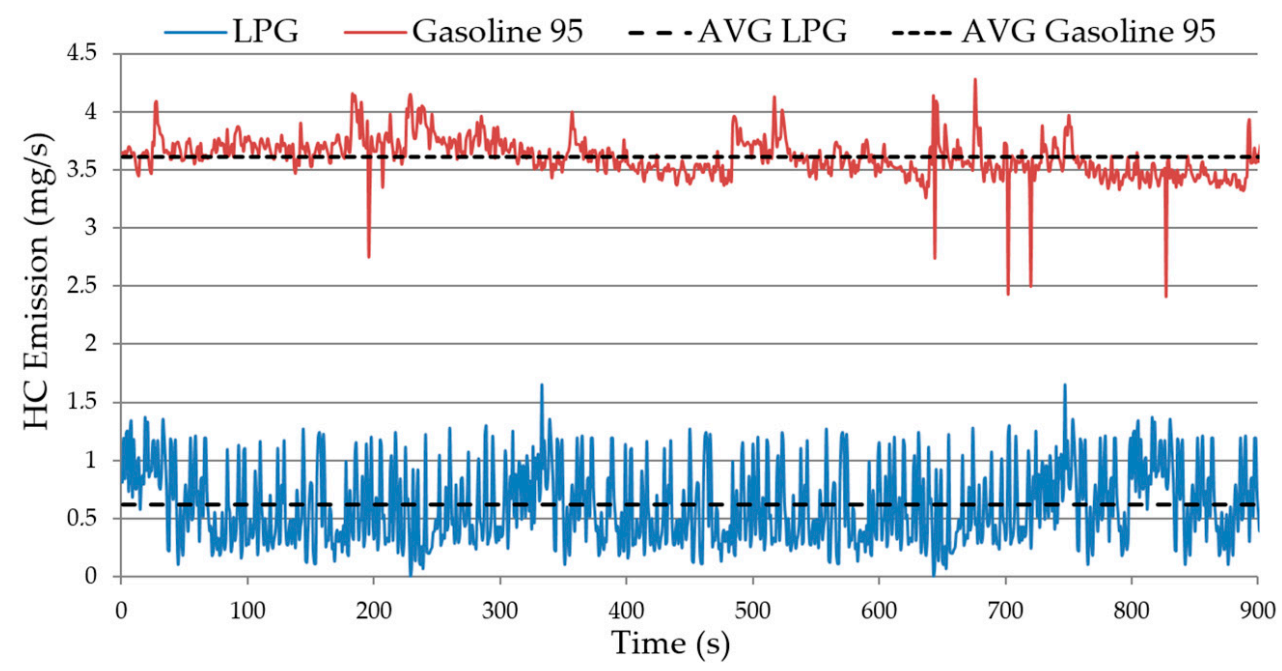

Figure 8. HC emission as a time function during the chipping process.

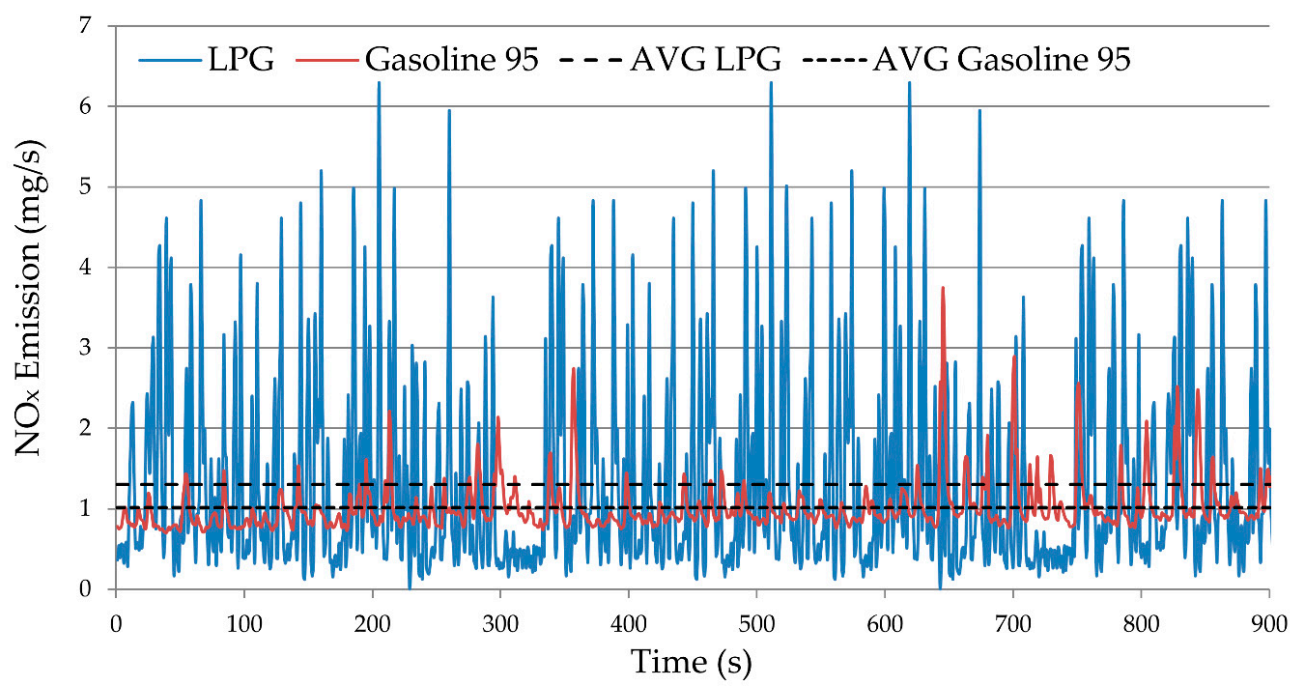

Figure 9. $\mathrm{NO}_{\mathrm{x}}$ emission as a time function during the chipping process.

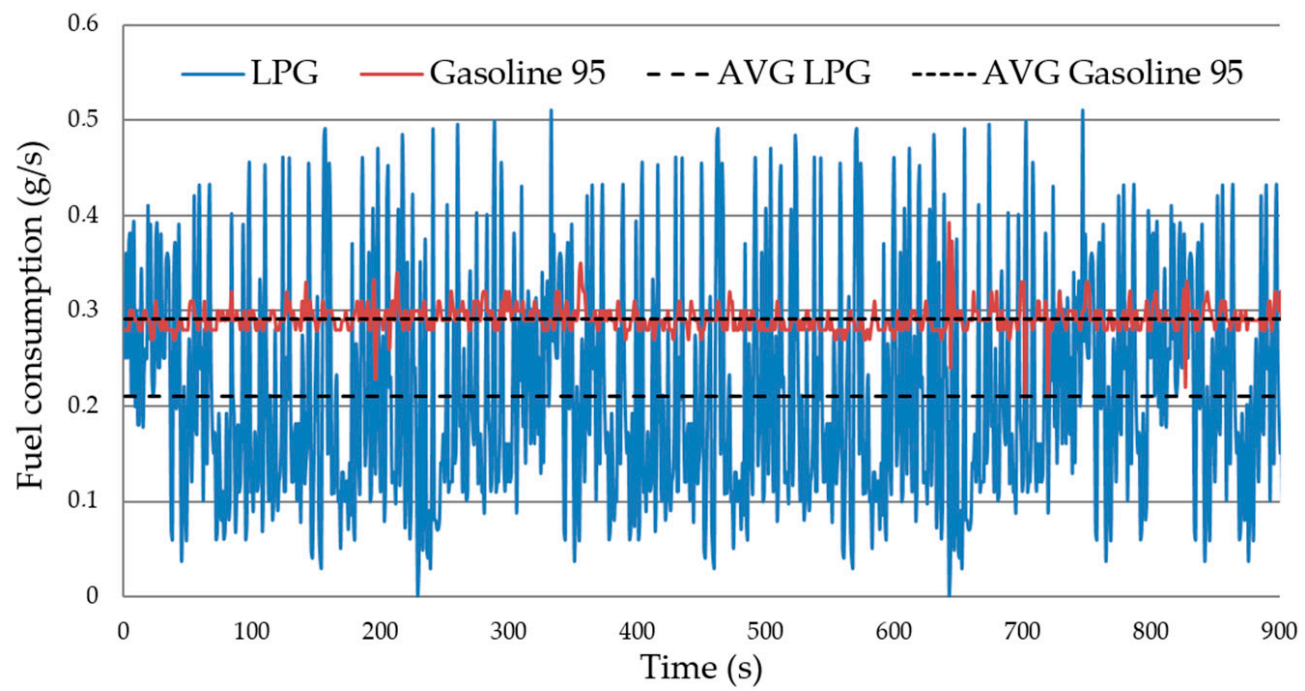

Figure 10. Fuel consumption as a time function during the chipping process. 


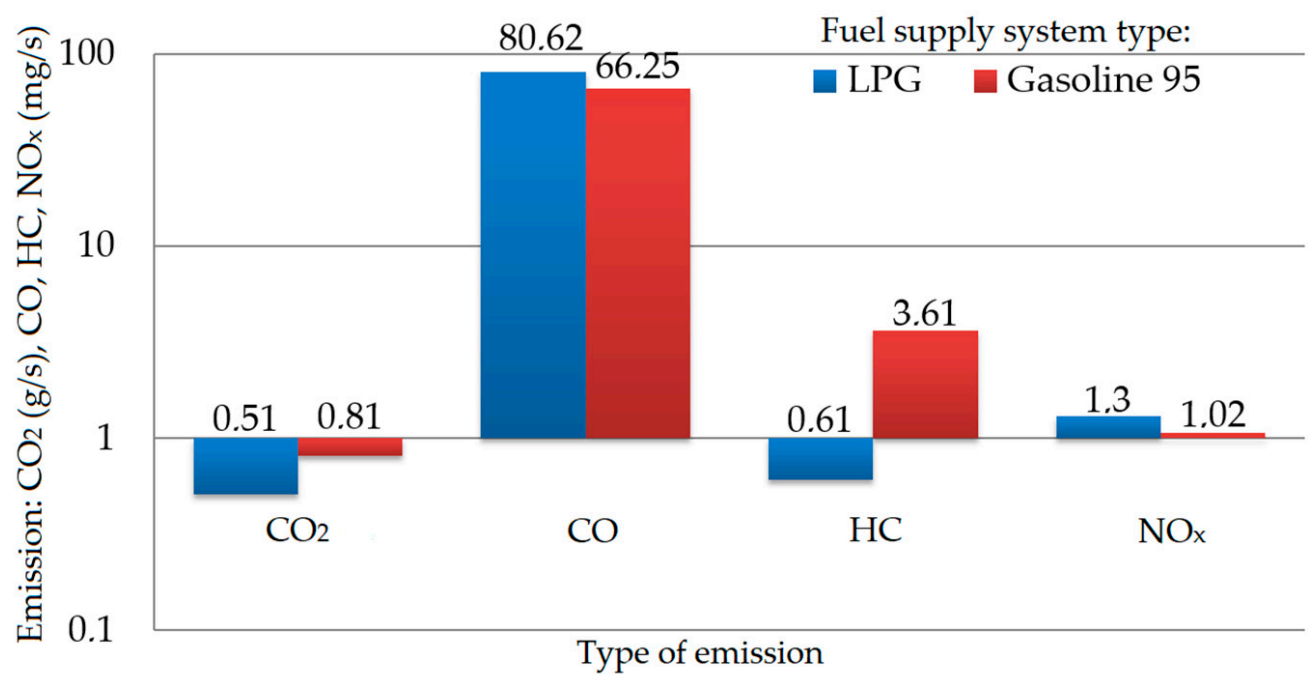

Figure 11. Comparison of emissions from engine fueled by gasoline 95 and LPG.

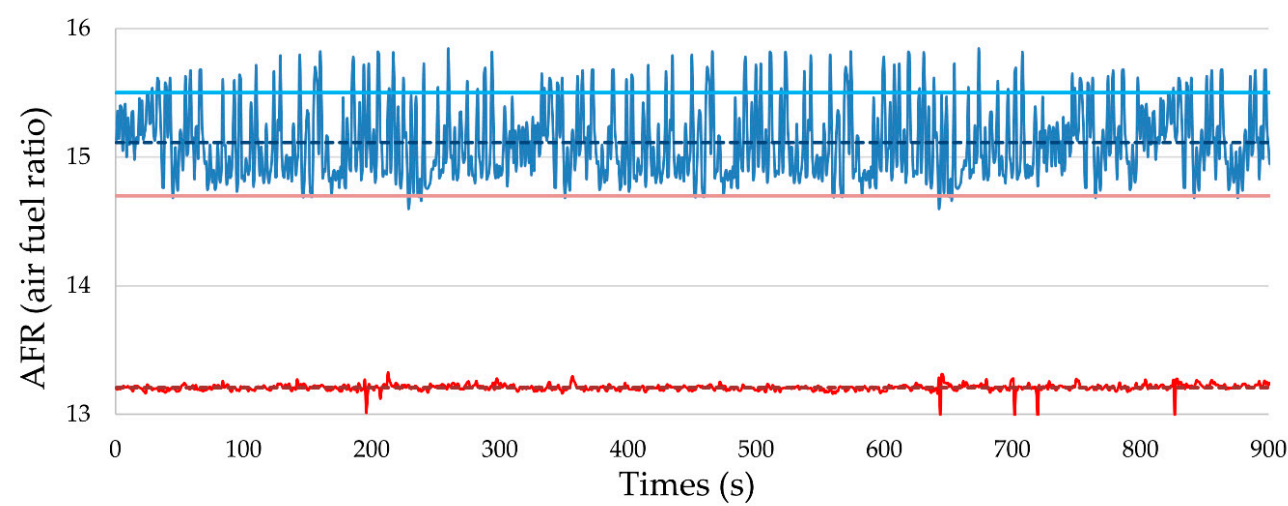

LPG:

AFR of the chopping process

Gasoline 95:

AVG AFR of the chopping process

- AFR of the chopping process

----- AVG AFR of the chopping process

AFR for a stoichiometric mixture

- AFR for a stoichiometric mixture

Figure 12. Air-fuel ratio (AFR) characteristics for the engine powered by gasoline and LPG.

\section{Discussion}

For efficient control of the drive unit and to evaluate the reaction of the tested design to changes in the operating conditions, it is important to measure the emission of the generated exhaust gas compounds as a function of time. The results may indicate areas that require improvements in the design. The results of the exhaust emission tests with their average values per specific time interval are equally important (Figure 11). They enable a comparison of the data on selected designs and provide information on the impact of selected machines on global or local exhaust emissions. Comparison of the tested designs are presented (gasoline 95 and LPG) in Figure 13, with the percentage comparison calculated according to Equation (2):

$$
A / B=-\frac{x_{A}-x_{B}}{x_{A}} \cdot 100 \%,
$$

where $x_{A}$ is the selected value for the gasoline 95 fuel supply system, $x_{B}$ is the selected value for the LPG fuel supply system. Equation (2) is written in such a form that drops in the value are negative and increases in the value are positive. 


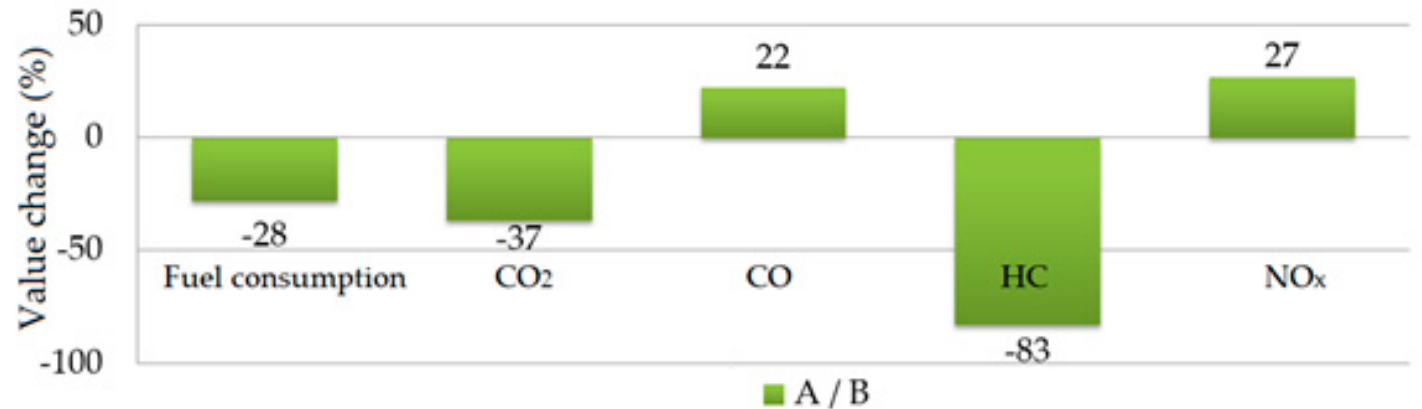

Figure 13. Influence of the fuel supply system on selected values of exhaust emissions and fuel consumption, where: A-gasoline 95 fuel supply system, B-LPG fuel supply system.

The use of the LPG system increased the emissions of, $\mathrm{CO}$ by $22 \%$, and $\mathrm{NO}_{x}$ by $27 \%$ compared to the engine with the classic gasoline 95 carburetor system. On the other hand, the beneficial effect of using the LPG system was the reduction of $\mathrm{HC}$ emissions by $83 \%$ and $\mathrm{CO}_{2}$ emissions by $37 \%$. The use of an LPG system allowed to reduce fuel consumption by $28 \%$, which is a good result.

Exhaust gas emission is most often expressed in $\mathrm{g} / \mathrm{km}$ or $\mathrm{g} / \mathrm{kWh}$. The data collected in the literature review refer to various physical quantities. To make them comparable, it is necessary to transform them. Thus, exhaust emissions $(E E)$ expressed in $(\mathrm{g} / \mathrm{h})$ were determined based on the nominal power of the machine $P$ given in $\mathrm{kW}$ and the exhaust emissions depending on the power of the machine $E$ expressed in $\mathrm{g} / \mathrm{kWh}$. For this purpose, we used the relationship defined by Equation (3):

$$
E E=E \cdot P
$$

In other words, the procedure described for determining the value $E E$ assumes an hour of machine operation at full power.

The permissible limits for the harmful compounds in exhaust gas emission for the tested group of propulsion units according to the provisions in force in the European Union from 2019 are presented in Table 6 [11]. These engines are subject to the NRS-vr/vi-1b category, according to Stage V emission standards for non-handheld spark ignition SI engines below $56 \mathrm{~kW}$ (NRS).

Table 6. Stage V emission standards for non-handheld SI engines below $19 \mathrm{~kW}$ (NRS), an engine displacement greater than or equal to $225 \mathrm{~cm}^{3}$ (A), and theoretically permitted exhaust emissions in the European Union for $10 \mathrm{~kW}$ engines during an hour of operation (B).

\begin{tabular}{ccccccc}
\hline & \multirow{2}{*}{ Category } & \multirow{2}{*}{ Power $(\boldsymbol{P})$} & Engine Displacement $(\boldsymbol{V})$ & Date & \multicolumn{2}{c}{ Permitted Emission } \\
\cline { 6 - 7 } & & & & CO & HC + NOx \\
\hline A & NRS-vr/vi-1b & $P<19 \mathrm{~kW}$ & $V \geq 225 \mathrm{~cm}^{3}$ & 2019 & $610 \mathrm{~g} / \mathrm{kWh}$ & $8 \mathrm{~g} / \mathrm{kWh}$ \\
\hline B & NRS-vr/vi-1b & $\approx 10 \mathrm{~kW}$ & $390 \mathrm{~cm}^{3}$ & 2019 & $6100 \mathrm{~g} / \mathrm{h}$ & $80 \mathrm{~g} / \mathrm{h}$ \\
\hline
\end{tabular}

Therefore, a comparison of permissible emissions and approximate emissions from the tested engines was made (Table 6). The results indicate that the drives in question do not exceed the limits allowed in the European Union during one hour of operation (Figure 14). However, it should be borne in mind that the engines tested in real operating conditions were not characterized by the maximum load. The comparisons presented in Figures 13 and 14 show the emissions from gasoline and LPG engines and the exhaust emissions of the tested constructions with exhaust emission limits in Europe. The absolute number of measurements for consumption and emissions are for comparison purposes only. 


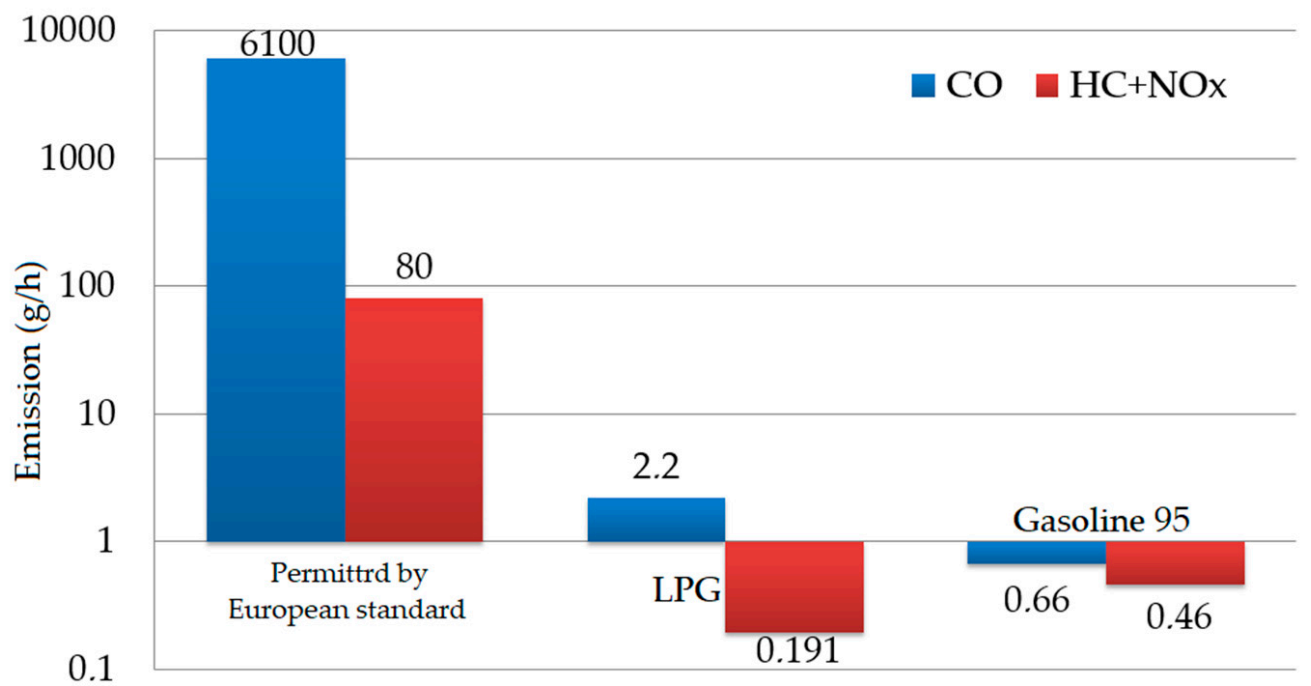

Figure 14. Comparison of the exhaust emissions of the tested designs with the exhaust emission limits in Europe.

The results of air pollutant emission tests during LPG combustion are characterized by higher emissions of harmful compounds in terms of $\mathrm{CO}$ and $\mathrm{NO}_{\mathrm{x}}$ emissions and lower in terms of $\mathrm{CO}_{2}$ and HC emissions compared to gasoline 95 . Such results partially coincide with the studies presented in the literature [29], which indicate that higher emissions might characterize low-tech gas installations in vehicles. On the other hand, studies in which the use of LPG fuel and the injection system, i.e., a system with a higher technical advancement level, may be characterized by favorable results of harmful emissions, as shown by other studies presented in the literature [30]. Good ecological and economical properties characterize technologies of LPG installations used in modern motor vehicle engines, however, the transfer of these systems to small power engines is difficult. Modern LPG systems require cooling with the coolant from the internal combustion engine and require a permanent battery power supply system. This contributes to the basic problems of using these components in small engines. Most of these engines are air-cooled and have no battery. Further, technologically advanced LPG systems require, among others, the measurement of crankshaft rotational speed, camshaft position, engine load, oxygen content in exhaust gases, and engine temperature. Engines equipped with gasoline 95 injection systems already have such elements; hence their modernization with LPG systems is simpler and cheaper. The most technically advanced small commercial engine in the $390 \mathrm{~cm}^{3}$ capacity range is the Honda iGX390. Of the above-mentioned elements and sensors that are beneficial in the application of LPG systems dedicated to car engines, the Honda iGX390 has rotational speed measuring sensors and a battery. The introduction of changes necessary in the use of car components in small engines is associated with design changes resulting from the introduction of measuring sensors. Besides, all components necessary to run this type of construction may exceed the cost of purchasing a small engine without an LPG installation. In order to implement the technology of powering small engines with alternative fuels such as LPG, it is necessary to search for cheap and simple design solutions adapted to the characteristics of the tested engines.

\section{Conclusions}

Researching innovative solutions that are ready for implementation is as important as developing solutions that are still clearly far from implementation for various reasons, e.g., production costs, availability of components, or materials. The authors tested a small, gasoline 95 powered engine (with a carburetor fuel system). Later, they modernized the system to power the same engine (also with carburetor) with an LPG. The test was carried out in real working conditions, and the drives were mounted in a cylindrical chipper designed for branches with a diameter of up to $80 \mathrm{~mm}$. 
Chipper equipped with an LPG system was characterized by a higher emission of harmful exhaust compounds: $\mathrm{CO}$ by $22 \%, \mathrm{NO}_{x}$ by $27 \%$ compared to the engine with the classic gasoline 95 carburetor system during the actual operation of the machine (while shredding branches). The engine after modernization enabling the use of LPG fuel, showed an $83 \%$ lower HC emission and reduction in $\mathrm{CO}_{2}$ emission by $37 \%$ as well as lower fuel consumption by $28 \%$. It should be emphasized that the performed tests are one of the first concerning small engine measurements in real operating conditions, using PEMS equipment. Increased fuel consumption when using LPG over gasoline 95 is common [46], however, the developed structure showed lower LPG fuel consumption despite its lower calorific value. This is due to the mixture composition control characteristic, where the gasoline-powered engine during loading was characterized by a rich mixture (avg AFR $\approx 13.2 \pm 0.03$ ), whereas the LPG engine operated on a slightly enriched mixture (avg AFR $\approx 15.1 \pm 0.3$ ). A positive aspect of the decreased LPG consumption and its lower price is the operating cost reduction. This is particularly important in Europe as the difference in gasoline 95 and LPG prices on this continent is on average around $0.2 \mathrm{EUR} / \mathrm{h}$. The LPG fuel system, despite the increased emission of selected exhaust gas components compared to the gasoline 95 carburetor system, does not exceed the European exhaust standards for small engines for non-road applications. This proves that carburetor fuel supply systems can meet the applicable standards in the European Union, even though in other industries, e.g., transport, such systems did not meet the emission requirements. Further research and work should be carried out in the direction of the technical development of fuel supply systems and tightening the regulations that will prevent the use of simple fuel supply systems and will enable the introduction to the market competitive and more advanced fuel injection systems [10,47].

The authors researched systems that adapt the character of low-power motors operation to the real work conditions $[19,47]$. The results of their work show a reduction in fuel consumption and exhaust emissions of $\mathrm{CO}, \mathrm{CO}_{2}$, and $\mathrm{NO}_{x}$; however, the developed system is characterized by increased $\mathrm{HC}$ emissions when running on gasoline. The research presented in this paper shows that the use of LPG fuel can reduce HC emissions by about $83 \%$, which may suggest that LPG is the recommended fuel for use in adaptive systems. This statement is supported by the fact that LPG is a fuel with a lower carbon content than gasoline 95 and may contribute to lower HC emissions in the described systems, the increased emission of which is caused by unburned fuel particles.

Author Contributions: Conceptualization, Ł.W., P.L., and M.K.; methodology, Ł.W., P.L., M.D., and F.M.; software, Ł.W. and M.D.; validation, Ł.W., M.K., and P.L.; formal analysis, Ł.W., P.L., and M.K.; investigation, Ł.W. and P.L.; resources, Ł.W., M.D., and F.M.; data curation, Ł.W.; writing-original draft preparation, Ł.W., M.K., and P.L.; writing—review and editing, M.K., P.L., and Ł.W.; visualization, Ł.W. and M.K.; supervision, Ł.W. and P.L.; project administration, Ł.W.; funding acquisition, Ł.W. All authors have read and agreed to the published version of the manuscript.

Funding: Research was performed as part of the project “Interdisciplinary Dean's Grant (IDG) of Poznan University of Technology" determined in the subject for the 2020 year-air quality in Poznan and how to improve it. Project title: "Design and research of mobile machines chipping wastes from urban agriculture processes for innovative construction solutions limiting the impact on the natural environment and machine operators" (33/32/SIGR/3334) financed by the Poznan University of Technology.

Acknowledgments: For the employees of Internal Combustion Engines and Drives, Faculty of Civil Engineering and Transport, Poznan University of Technology: Paweł Fuć, Łukasz Rymaniak, Andrzej Ziółkowski for his help in describing the methodology of measuring exhaust emissions.

Conflicts of Interest: The authors declare no conflict of interest.

\section{References}

1. Smurzyńska, A.; Czekała, W.; Hektus, P.; Marks, S.; Mazurkiewicz, J.; Brzoski, M.; Chełkowski, D.; Kozłowski, K. Poznań air pollution analysis for 2015-2017. J. Ecol. Eng. 2018, 19, 162-169. [CrossRef]

2. Gu, H.; Cao, Y.; Elahi, E.; Jha, S.K. Human health damages related to air pollution in China. Environ. Sci. Pollut. Res. 2019, 26, 13115-13125. [CrossRef]

3. Jury, M.R. Meteorology of air pollution in Los Angeles. Atmos. Pollut. Res. 2020, 11, 1226-1237. [CrossRef] 
4. Marchant-Fuentes, C.; Leiva, V.; Christakos, G.; Cavieres, M.F. Monitoring urban environmental pollution by bivariate control charts: New methodology and case study in Santiago, Chile. Environmetrics 2019, 30, e2551.

5. Paton-Walsh, C.; Rayner, P.; Simmons, J.; Fiddes, S.L.; Schofield, R.; Bridgman, H.; Beaupark, S.; Broome, R.; Chambers, S.D.; Chang, L.T.-C.; et al. A clean air plan for Sydney: An overview of the special issue on air quality in New South Wales. Atmosphere 2019, 10, 774. [CrossRef]

6. Hassan, S.K.; Khoder, M.I. Chemical characteristics of atmospheric PM2.5 loads during air pollution episodes in Giza, Egypt. Atmos. Environ. 2017, 150, 346-355. [CrossRef]

7. Guneroglu, N.; Bekar, M.; Kaya Sahin, E. Plant selection for roadside design: "The view of landscape architects". Environ. Sci. Pollut. Res. 2019, 26, 34430-34439. [CrossRef]

8. Alotaibi, M.D.; Alharbi, B.H.; Al-Shamsi, M.A.; Alshahrani, T.S.; Al-Namazi, A.A.; Alharabi, S.F.; Alotaibi, F.S.; Qian, T. Assessing the response of five tree species to air pollution in Riyadh City, Saudi Arabia, for potential green belt application. Environ. Sci. Pollut. Res. 2020, 27, 29156-29170. [CrossRef]

9. Javanmard, Z.; Kouchaksaraei, M.T.; Hosseini, S.M.; Pandey, A.K. Assessment of anticipated performance index of some deciduous plant species under dust air pollution. Environ. Sci. Pollut. Res. 2020, 27, 38987-38994. [CrossRef]

10. Warguła, Ł.; Kukla, M.; Krawiec, P.; Wieczorek, B. Reduction in Operating Costs and Environmental Impact Consisting in the Modernization of the Low-Power Cylindrical Wood Chipper Power Unit by Using Alternative Fuel. Energies 2020, 13, 2995. [CrossRef]

11. EU. Regulation (EU) No 2016/1628 of the European Parliament and of the Council of 14 September 2016. On Requirements for Emission Limit Values of Gaseous and Particulate Pollutants and Type-Approval with Respect to Internal Combustion Engines for Mobile Machines Non-Road, Amending Regulations (EU) No 1024/2012 and (EU) No 167/2013 and Amending and Repealing Directive 97/68/WE.; EU: Brussels, Belgium, 2016.

12. Warguła, Ł.; Kukla, M.; Krawiec, P.; Wieczorek, B. Impact of Number of Operators and Distance to Branch Piles on Woodchipper Operation. Forests 2020, 11, 598. [CrossRef]

13. Waluś, K.J.; Warguła, Ł.; Krawiec, P.; Adamiec, J.M. Legal regulations of restrictions of air pollution made by non-road mobile machinery-The case study for Europe: A review. Environ. Sci. Pollut. Res. 2018, 25, 3243-3259. [CrossRef]

14. Warguła, Ł. Innovative injection-ignition system in a non-road small engine-Construction system. In Proceedings of the 23rd International Scientific Conference, Palanga, Lithuania, 2-4 October 2019; pp. 931-935.

15. Mahmoudzadeh Andwari, A.; Said, M.F.M.; Aziz, A.A.; Esfahanian, V.; Salavati-Zadeh, A.; Idris, M.A.; Perang, M.R.M.; Jamil, H.M. Design, modeling and simulation of a high-pressure gasoline direct injection (GDI) pump for small engine applications. J. Mech. Eng. 2018, 6, 107-120.

16. Niinikoski, J.; Ewalds, J.; Heikkinen, E.; Kotilainen, J.; Kääriäinen, M.; Tammi, K.; Kiviluoma, P.; Korhonen, A.; Kuosmanen, P. Methods for reducing emissions of small internal combustion engines. In Proceedings of the 11th International DAAAM Baltic Conference, Industrial Engineering, Tallinn, Estonia, 20-22 April 2016.

17. Warguła, Ł.; Waluś, J.K.; Krawiec, P. Determination of working conditions of mobile chipping wood machines in the aspect of innovative drive control systems. Sylwan 2019, 163, 765-772.

18. Warguła, Ł.; Wojtkowiak, D.; Waluś, K.J.; Krawiec, P.; Wieczorek, B. The analysis of the efficiency of the control system of wood chipper's driver with spark-ignition engine based on Skoda combustion engine $1.459 \mathrm{~kW}$. In Proceedings of the 21st International Scientific Conference, Juodkrante, Lithuania, 20-22 September 2017; pp. 452-458.

19. Warguła, Ł.; Kukla, M.; Lijewski, P.; Dobrzyński, M.; Markiewicz, F. Influence of Innovative Woodchipper Speed Control Systems on Exhaust Gas Emissions and Fuel Consumption in Urban Areas. Energies 2020, 13, 3330. [CrossRef]

20. Kim, H.C.; Park, K.; Nam, M.H.; Park, W.S. Analysis of component damage probability of a small engine based on penetration experiments and M \& S. J. Mech. Sci. Technol. 2020, 34, 765-775.

21. Li, L.; Wang, Z.; Deng, B.; Han, Y.; Wang, H. Combustion and Emissions Characteristics of a Small Spark-Ignited LPG Engine. SAE Technical Paper 01-1738, 2002. Available online: https://www.sae.org/ publications/technical-papers/content/2002-01-1738/ (accessed on 4 November 2020).

22. Li, L.; Liu, Z.; Wang, H.; Deng, B.; Wang, Z.; Xiao, Z.; Su, Y.; Jiang, B. Development of a Gas-phase LPG Injection System for a Small SI Engine. SAE Technical Paper 01-3260, 2003. Available online: https://www.sae.org/publications/technical-papers/content/2003-01-3260/ (accessed on 4 November 2020). 
23. Sulaiman, M.Y.; Ayob, M.R.; Meran, I. Performance of single cylinder spark ignition engine fueled by LPG. Procedia Eng. 2013, 53, 579-585. [CrossRef]

24. bin Mohd Zain, M.S.; bin Mohamed Soid, S.N.; bin Mior Abd Majid, M.F.; bin Zahelem, M.N. Performance characteristics of a small engine fueled by liquefied petroleum gas. In Advanced Engineering for Processes and Technologies. Advanced Structured Materials; Ismail, A., Abu Bakar, M., Öchsner, A., Eds.; Springer: Berlin, Germany; Cham, Germany, 2019; Volume 102, pp. 207-214.

25. Sabariah, M.S.; Nabilah, A.S.; Rosli, A.B.; Junaidi, Z.Z.; Mustafar, M.T. Analysis and simulation of combustion and emission on small engine. In IOP Conference Series: Materials Science and Engineering; UMP Pekan: Pahang, Malaysia, 2019; Volume 469.

26. Schirmer, W.N.; Olanyk, L.Z.; Guedes, C.L.B.; Quessada, T.P.; Ribeiro, C.B.; Capanema, M.A. Effects of air/fuel ratio on gas emissions in a small spark-ignited non-road engine operating with different gasoline/ethanol blends. Environ. Sci. Pollut. Res. 2017, 24, 20354-20359. [CrossRef]

27. Ribeiro, C.B.; Martins, K.G.; Gueri, M.V.D.; Pavanello, G.P.; Schirmer, W.N. Effect of anhydrous ethanol/gasoline blends on performance and exhaust emissions of spark-ignited non-road engines. Environ. Sci. Pollut. Res. 2018, 25, 24192-24200. [CrossRef]

28. Warguła, Ł.; Waluś, K.J.; Krawiec, P.; Polasik, J. Electronic control injection-ignition systems in propulsion of non-road mobile machinery. J. Mech. Trans. Eng. 2018, 70, 61-78.

29. Merkisz, J.; Radzimirski, S. Is propane-butane gas an ecological fuel? (original text in Polish: Czy gaz propan-butan jest paliwem ekologicznym?). Combust. Engines 2006, 45, 45-57.

30. Tasic, T.; Pogorevc, P.; Brajlih, T. Gasoline and LPG exhaust emissions comparison. Adv. Prod. Eng. Manag. 2011, 6, 87-94.

31. Passos, F.; Bressani-Ribeiro, T.; Rezende, S.; Chernicharo, C.A.L. Potential Applications of Biogas Produced in Small-Scale UASB-Based Sewage Treatment Plants in Brazil. Energies 2020, 13, 3356. [CrossRef]

32. The Price of 95 Gasoline and LPG. Available online: https://www.mylpg.eu (accessed on 20 July 2020).

33. The Price of 95 Gasoline and LPG. Available online: https://pl.globalpetrolprices.com (accessed on 20 July 2020).

34. Aydin, M.; Irgin, A.; Çelik, M.B. The Impact of Diesel/LPG Dual Fuel on Performance and Emissions in a Single Cylinder Diesel Generator. Appl. Sci. 2018, 8, 825. [CrossRef]

35. Rimkus, A.; Stravinskas, S.; Matijošius, J. Comparative Study on the Energetic and Ecologic Parameters of Dual Fuels (Diesel-NG and HVO-Biogas) and Conventional Diesel Fuel in a CI Engine. Appl. Sci. 2020, 10, 359. [CrossRef]

36. Rimkus, A.; Melaika, M.; Matijošius, J. Efficient and ecological indicators of CI engine fuelled with different diesel and LPG mixtures. Procedia Eng. 2017, 187, 504-512. [CrossRef]

37. Rimkus, A.; Matijošius, J.; Manoj Rayapureddy, S. Research of Energy and Ecological Indicators of a Compression Ignition Engine Fuelled with Diesel, Biodiesel (RME-Based) and Isopropanol Fuel Blends. Energies 2020, 13, 2398. [CrossRef]

38. Giechaskiel, B.; Lähde, T.; Gandi, S.; Keller, S.; Kreutziger, P.; Mamakos, A. Assessment of 10-nm Particle Number (PN) Portable Emissions Measurement Systems (PEMS) for Future Regulations. Int. J. Environ. Res. Public Health 2020, 17, 3878. [CrossRef]

39. Warguła, Ł.; Waluś, K.J.; Krawiec, P.; Kukla, M. Research of the ignition advance angle characteristics on the example of a German GX 390 combustion engine. Autobusy Technol. Eksploat. Syst. Transp. 2017, 12, 1387-1391.

40. Merkisz, J.; Dobrzyński, M.; Kozak, M.; Lijewski, P.; Fuć, P. Environmental aspects of the use of cng in public urban transport. Altern. Fuels Technol. Environ. Cond. 2016. [CrossRef]

41. Warguła, Ł.; Kaczmarzyk, P.; Dziechciarz, A. The assessment of fire risk of non-road mobile wood chopping machines. J. Res. Appl. Agric. Eng. 2019, 64, 58-64.

42. Bektas, I.; Alma, M.H.; As, N. Determination of the relationships between Brinell and Janka hardness of eastern beech (Fagus orientalis Lipsky). For. Prod. J. 2001, 51, 84.

43. Green, D.W.; Begel, M.; Nelson, W. Janka Hardness Using Nonstandard Specimens; US Department of Agriculture, Forest Service, Forest Product Laboratory: Washington, DC, USA, 2006; p. 303.

44. Lijewski, P.; Fuć, P.; Markiewicz, F.; Dobrzański, M. Problems of exhaust emissions testing from machines and mobile devices in real operating conditions. Combust. Engines 2019, 179, 292-296. 
45. Hernik, H.; Hans-Jurgen, R. Electronical Engineering in Motor Vehicles, Orginal Title in Polish: Elektrotechnika $i$ Elektronika w Pojazdach Samochdowych; WKE: Warszawa, Poland, 2013; ISBN 978-83-206-1921-8.

46. Szpica, D.; Czaban, J. Operational assessment of selected gasoline and LPG vapour injector dosage regularity. Mechanics 2014, 20, 480-488. [CrossRef]

47. Warguła, Ł.; Krawiec, P.; Waluś, K.J.; Kukla, M. Fuel Consumption Test Results for a Self-Adaptive, Maintenance-Free Wood Chipper Drive Control System. Appl. Sci. 2020, 10, 2727. [CrossRef]

Publisher's Note: MDPI stays neutral with regard to jurisdictional claims in published maps and institutional affiliations.

(C) 2020 by the authors. Licensee MDPI, Basel, Switzerland. This article is an open access article distributed under the terms and conditions of the Creative Commons Attribution (CC BY) license (http://creativecommons.org/licenses/by/4.0/). 